\title{
EARLY EMBRYO MORTALITY IN HEIFERS ISOIMMUNIZED WITH SEMEN AND CONCEPTUS*
}

\author{
A. G. MENGE $\dagger$ \\ Department of Animal Sciences, New Jersey Agricultural Station, \\ Sussex, New Fersey, U.S.A. \\ (Received 8th February 1968)
}

\begin{abstract}
Summary. Isoimmunization of heifers by a single injection of semen and complete Freund's adjuvant up to 21 days after insemination resulted in a high incidence of early embryo loss. The heifers had a pregnancy rate of $11.8 \%$ and an incidence of delayed returns to oestrus of $41.3 \%$. Only one of ten heifers immunized with semen had a fertilized ovum at slaughter after the second to fifth insemination. Pregnancy occurred in eight of ten control heifers immunized with seminal plasma after insemination.

Heifers immunized with homologous conceptus material and adjuvant by repeated intra-uterine and intradermal injections required an average of 3.8 inseminations per pregnancy. The infertility was apparently due to early embryo death. Isoimmunization with seminal plasma and immature testis, and the treatment of semen with antisera to conceptus and immature testis, had no effect on fertility in heifers.
\end{abstract}

\section{INTRODUCTION}

Infertility in the female has been induced in several mammalian species by immunization with homologous semen, spermatozoa and testis. In mice, McLaren (1964) reported that the induced infertility was due to inhibition of fertilization. Data from rabbits, however, indicated that isoimmunization with semen and testis decreased the rate of embryo survival as well as the fertilization rate (Menge, 1968). This study also indicated that immunization with homologous conceptus material lowered embryo survival, whereas immunization with seminal plasma had no effect on fertility. Fertilization is inhibited in cattle by treating semen with anti-semen sera before insemination (Menge, Stone, Tyler \& Casida, 1962). Heifers isoimmunized with semen and testis experienced a period of infertility during which time there was an indication of early embryo mortality (Menge, 1967). The present study was undertaken to determine the effects of isoimmunization with semen, seminal plasma and conceptus on early embryo survival in cattle.

\footnotetext{
* Paper of the Journal Series, New Jersey Agricultural Experiment Station, Rutgers-The State University, New Brunswick.

$\dagger$ Present address: Center for Research in Reproductive Biology, Department of Obstetrics and Gynecology, University of Michigan Medical Center, Ann Arbor, Michigan 48104, U.S.A.
} 


\section{MATERIALS AND METHODS}

The antigenic materials used in the study consisted of semen from the pooled ejaculates of two bulls; seminal plasma from a bull in which the caput epididymidis had been severed from the testes prepuberally; pooled conceptus material from five normal heifers killed from 32 to 38 days of pregnancy; and immature testis material from a 3-month-old bull calf. Semen and seminal plasma were collected with an artificial vagina. The spermatozoal concentration was determined photometrically. Semen used for injection was concentrated by centrifugation to contain approximately $4 \times 10^{9}$ spermatozoa $/ \mathrm{ml}$. Conceptuses, after recovery from heifers at slaughter, were cooled and homogenized at $5^{\circ} \mathrm{G}$. The conceptus material was dialysed against cold distilled water for $24 \mathrm{hr}$ and then lyophilized. Before use, a $5 \%$ suspension of conceptus in physiological saline was prepared. The testes, which were in the spermatogonial stage, were homogenized in an equal volume of saline. The antigenic materials were thoroughly mixed with an equal volume of complete Freund's adjuvant before injection. An intradermal injection, unless otherwise specified, consisted of $2 \mathrm{ml}$ of antigen-adjuvant mixture given in $0 \cdot 1-$ to $0 \cdot 2-\mathrm{ml}$ amounts at multiple sites in the shoulder region. An intra-uterine injection consisted of $2 \mathrm{ml}$ of material instilled into the uterine lumen with a 20 in. $14 \mathrm{G}$ stainless steel catheter.

Dairy-type virgin heifers, mostly of Holstein breeding and exhibiting normal length oestrous cycles, were used throughout the study. In the first experiment, eleven heifers were artificially inseminated from 3 to 4 months after intradermal injection of $1 \mathrm{ml}$ of semen-adjuvant mixture. This was the time required for the serum titres of sperm agglutinins to decline to pre-injection levels. One or 2 days after insemination five of the heifers were immunized with seminal plasma and the six remaining heifers with semen. Of an additional thirty-seven heifers that were artificially inseminated, five were immunized with seminal plasma on Days 1 or 2 and 7, and the remaining heifers were immunized with semen on Days 1 or $2,10,13,15,17,19$ or 21 after insemination. Five of the seminalplasma control heifers, after they were diagnosed pregnant from 32 to 36 days after breeding, were injected with semen and adjuvant. In these experiments, the heifers were bred only after oestrous cycles of 18 to 22 days in length.

In the second portion of the study, twenty-three heifers were isoimmunized with conceptus material, fifteen by intradermal injection and eight by intrauterine injection. The injections were given once weekly for 3 to 4 weeks, followed by a final injection within 3 to 5 weeks. The last intradermal injection was given from 6 to 10 days before insemination, whereas the final intra-uterine injection was given one oestrous cycle before insemination. Isoimmunization with seminal plasma served as a control in three heifers given four intradermal injections and in five heifers given four or five intra-uterine injections. Two additional heifers were given three intradermal injections of immature testes over a 5-week period with the last injection administered 1 week before insemination.

The heifers were artificially inseminated with $1 \mathrm{ml}$ of extended semen containing a minimum of $15 \times 10^{6}$ motile spermatozoa. The semen, after collection with an artificial vagina from the two bulls whose semen was used for injection, 
was extended to $30 \times 10^{6}$ spermatozoa/ml with a $20 \%$ egg yolk-citrate diluent containing antibiotics. The diluted semen was used immediately or cooled slowly and stored at $5^{\circ} \mathrm{C}$ until needed. Treatment of semen with antisera was done by diluting freshly collected semen with a modified Krebs solution to approximately $60 \times 10^{6}$ spermatozoa $/ \mathrm{ml}$ and then incubating $1 \mathrm{ml}$ of diluted semen with $1 \mathrm{ml}$ of antisera for 20 to $30 \mathrm{~min}$ at room temperature before inseminating the heifers.

The reproductive organs of the heifers were examined regularly by rectal palpation to determine the occurrence of ovulation, abnormalities and pregnancy.

Serum samples were obtained from the heifers by venous puncture before and after immunization. Rabbit antiserum to bovine conceptus or immature testis was prepared in two rabbits each by 3 weekly intramuscular and subcutaneous injections of $0.5 \mathrm{ml}$ of tissue and adjuvant, followed in 3 weeks by a fourth injection of $1 \mathrm{ml}$ of the material. One week after the last injection the rabbits

TABLE 1

PREGNANGY RATE IN HEIFERS ISOIMMUNIZED WITH SEMINAL PLASMA AND SEMEN AT DIFFERENT TIMES AFTER INSEMINATION

\begin{tabular}{|c|c|c|c|c|c|}
\hline $\begin{array}{l}\text { Isoimmunization, } \\
\text { day immunized }\end{array}$ & \multicolumn{2}{|c|}{$\begin{array}{l}\text { No. of heifers: } \\
\text { Inseminated Pregnant }\end{array}$} & \multicolumn{2}{|c|}{$\begin{array}{cc}\text { Return oestrous cycles } \\
\text { No. }>23 \text { days } \\
\begin{array}{c}\text { Av. length } \\
\text { (days) }\end{array}\end{array}$} & $\begin{array}{l}\text { Sperm agglutinin } \\
\text { titres (range)* }\end{array}$ \\
\hline $\begin{array}{c}\text { Seminal plasma } \\
1 \text { or } 2 \dagger \\
1 \text { or } 2,7\end{array}$ & $\begin{array}{l}5 \\
5\end{array}$ & $\begin{array}{l}3 \\
5\end{array}$ & $\begin{array}{l}0 \\
0\end{array}$ & $20 \cdot 0$ & $\begin{array}{l}64-256 \\
64-256\end{array}$ \\
\hline $\begin{array}{c}\text { Semen } \\
1 \text { or } 2 \dagger \\
1 \text { or } 2 \\
10 \\
13 \\
15 \\
17 \\
19 \\
21 \\
32 \text { to } 36\end{array}$ & $\begin{array}{r}6 \\
4 \\
10 \\
3 \\
3 \\
4 \\
4 \\
4 \ddagger \\
5\end{array}$ & $\begin{array}{l}1 \\
0 \\
2 \\
0 \\
1 \\
0 \\
0 \\
4 \\
5\end{array}$ & $\begin{array}{l}0 \\
1 \\
3 \\
0 \\
2 \\
3 \$ \\
4 \$ \\
-\end{array}$ & $\begin{array}{l}20 \cdot 2 \\
22 \cdot 8 \\
23 \cdot 3 \\
21 \cdot 3 \\
29 \cdot 0 \\
24 \cdot 0 \\
28 \cdot 4 \\
=-\end{array}$ & $\begin{array}{c}128-1024 \\
64-256 \\
128-512 \\
128-256 \\
128-256 \\
128-512 \\
128-512 \\
128-512 \\
128-1024\end{array}$ \\
\hline
\end{tabular}

* Serum sample obtained 7 to 9 days after immunization.

Heifers previously immunized with semen.

$¥$ One heifer returned to oestrus 20 days after first insemination and was immunized on 21 st day after second insemination.

$\$$ One heifer each was slaughtered in the 17- and 19-day groups at 27 and 33 days after insemination; no evidence of pregnancy nor of recent oestrus and ovulation.

were bled by cardiac puncture and the antiserum harvested. All serum samples were heated at $56^{\circ} \mathrm{C}$ for $30 \mathrm{~min}$ before use. Sperm-agglutinin titres were determined by the gelatin agglutination method (Kibrick, Balding \& Merrill, 1952). Complement fixation tests followed the procedures outlined by Campbell, Garvey, Cremer \& Sussdorf (1963).

\section{RESULTS}

Effect of isoimmunization with semen

Eight of ten heifers immunized with seminal plasma after insemination were diagnosed pregnant at 32 to 38 days after first insemination (Table 1). The 
two remaining heifers conceived after the second and third inseminations. Isoimmunization of thirty-four heifers with semen up to 19 days after insemination, however, reduced the pregnancy rate to $11.8 \%$. The pregnancies of heifers immunized with semen after this time were not affected. Of the treated heifers that returned to oestrus, ten were re-inseminated and slaughtered 3 days after the second to fifth insemination. Only one of ten ova recovered was fertilized, an apparently normal 8-cell zygote.

The incidence of delayed returns to oestrus ( $>23$ days) appeared to increase with an increase in the interval between insemination and immunization. The overall incidence of delayed returns to oestrus was $41.3 \%$. The pregnant heifers were slaughtered 38 to 50 days after insemination; each had a normal embryo.

Serum samples taken 7 to 9 days after immunization had titres of sperm agglutinins varying from $1: 64$ to $1: 256$ and $1: 64$ to $1: 1024$ for heifers immunized with seminal plasma and semen, respectively, compared with normal

TABLE 2

FERTILITY IN HEIFERS ISOIMMUNIZED WITH CONCEPTUS, SEMINAL PLASMA AND IMMATURE TESTIS

\begin{tabular}{c|c|c|c|cc}
\hline Immunizing treatment & $\begin{array}{c}\text { No. } \\
\text { heifers }\end{array}$ & $\begin{array}{c}\text { Insem./ } \\
\text { pregnancy }\end{array}$ & $\begin{array}{c}\text { No. return oestrous } \\
\text { cycles }>23 \text { days }\end{array}$ & \multicolumn{2}{|c|}{$\begin{array}{c}\text { Range of titres* } \\
\text { Serum }\end{array}$ Mucus } \\
\hline $\begin{array}{c}\text { Conceptus } \\
\text { Intra-uterine }\end{array}$ & 8 & $4 \cdot 0(1-10) \dagger \ddagger$ & 6 & $10-320$ & $10-20$ \\
$\quad$ Intradermal & 7 & $3 \cdot 6(2-6)$ & 4 & $10-160$ & $10-80$ \\
$\begin{array}{c}\text { Seminal plasma } \\
\text { Intra-uterine } \\
\text { Intradermal }\end{array}$ & 5 & $1 \cdot 2(1-2)$ & 0 & $16-64$ \\
Immature testis & 3 & $1 \cdot 0$ & - & $128-256$ \\
$\quad$ Intradermal & 2 & $1 \cdot 0$ & - & $16-32$ \\
\hline
\end{tabular}

* Titres are of complement-fixing antibodies for conceptus groups and of sperm agglutinins for the seminal plasma and immature-testis groups. Samples were obtained at first insemination.

$\dagger$ One heifer had an observed abortion 43 days after the third insemination.

$\ddagger$ Range given in parentheses.

serum values of $1: 4$ to $1: 16$. The titres of agglutinins were maximal 1 or 2 weeks after the single immunization. There appeared to be no association of serum titre with the reduction in pregnancy rate. The titres were still relatively high $(1: 32$ to $1: 128)$ in the heifers from which unfertilized ova were recovered.

\section{Effect of isoimmunization with conceptus}

Isoimmunization with conceptus material reduced fertility; heifers immunized by the intra-uterine and intradermal routes averaged 4.0 and 3.6 inseminations per pregnancy, respectively, compared with 1.2 and 1.0 inseminations per pregnancy, respectively, for control heifers immunized with seminal plasma by the same two routes (Table 2). Both heifers immunized with immature testis conceived at the first insemination. 
Delayed return intervals to oestrus other than those due to quiet ovulations occurred on six occasions in three heifers immunized by the intra-uterine route, and once in each of four heifers immunized intradermally. There was one diagnosed pregnancy lost in the treated groups.

Four heifers immunized with conceptus and slaughtered 3 days after insemination each had a fertilized ovum (Table 3). Of four additional immunized heifers, two were killed 16 days after insemination and two were allowed to return to oestrus or maintain a pregnancy. Neither of the two heifers killed at 16 days was pregnant, whereas one of the two remaining heifers became pregnant. The other heifer returned to oestrus and had a fertilized ovum at slaughter 3 days after the second insemination. Two control heifers had normal conceptuses

\section{TABLE 3}

FERTILIZATION AND EMBRYO SURVIVAL IN HEIFERS ISOIMMUNIZED WITH CONCEPTUS AND IN HEIFERS BRED WITH SEMEN TREATED WITH ANTISERUM

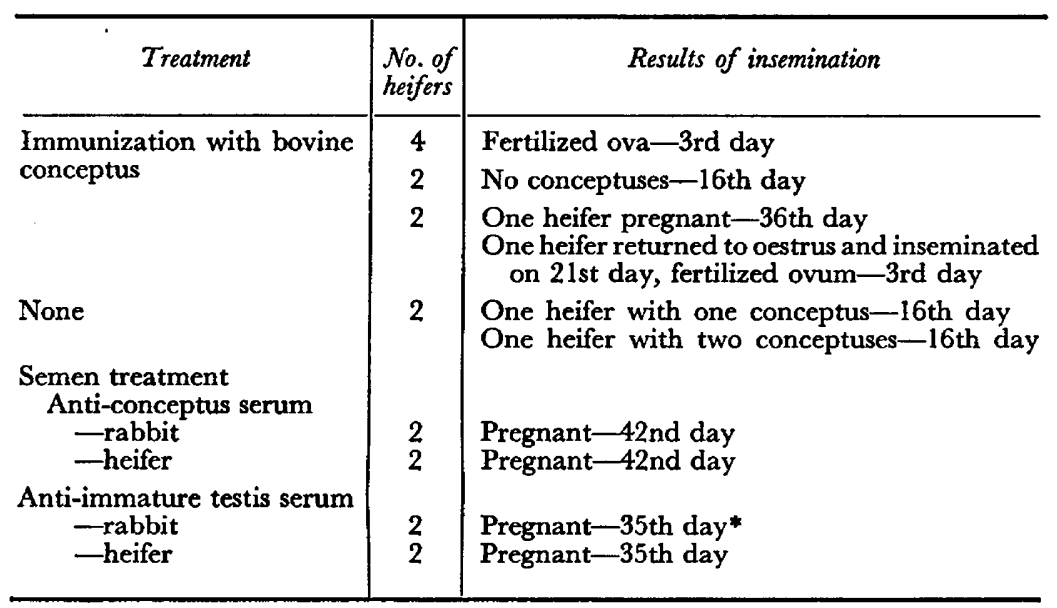

* One heifer inseminated twice.

at slaughter 16 days after breeding. Treating bull semen with rabbit or heifer anti-conceptus or anti-immature testis serum before insemination of eight heifers had no detrimental effects on fertility.

Three heifers, re-immunized with conceptus by intradermal injections during the 6th and 7th weeks of pregnancy and during the 3rd and 2nd weeks before the expected calving date, gave birth to normal calves.

Serum samples from heifers immunized with conceptus contained complement-fixing antibodies but no detectable levels of agglutinating or precipitating antibodies. The serum titres of complement-fixing antibodies varied from $1: 10$ to $1: 320$ and from $1: 10$ to $1: 160$ in the intra-uterine and intradermal injected heifers, respectively (Table 2). There was no significant association between serum titre and infertility. Titres in the vaginal mucus samples taken at first insemination varied from $1: 10$ to $1: 80$ with no relationship to fertility nor to the serum titres in either group of heifers. 


\section{DISCUSSION}

These results indicate that isoantibodies against semen can cause early embryo death as well as inhibition of fertilization. This supports the results of a previous study in which heifers isoimmunized with semen before breeding experienced an increased incidence of early embryo loss as indicated by delayed returns to oestrus (Menge, 1967). In the present study the incidence of delayed returns to oestrus increased with an increase in the post-breeding interval to injection up to the 21st day. Embryo losses induced by injections 1 or 2 days after insemination apparently occurred soon after injection, since there was no effect on cycle length, whereas approximately $50 \%$ of the heifers injected on the 10th day and $75 \%$ of those injected between 10 and 21 days after insemination experienced delayed return intervals. The sensitive period of the conceptus to isoantibodies against semen must extend from after fertilization up to approximately 24 to 26 days after insemination. The heifers responded rapidly to the immunization with semen. Serum samples were taken on alternate days from two heifers after an immunization and the titres of sperm agglutinins were observed to be rising by 3 days and were maximal by 9 and 11 days after injection.

The semen antigens capable of inducing the antifertility isoantibodies presumably originate in the testis after the spermatogonial stage of development, as antibodies to the antigens of seminal plasma and immature testis had no effect on fertility. The antigens are probably an integral part of the sperm cell, as suggested by results in rabbits in which washed epididymal spermatozoa were capable of inducing isoantibodies and infertility (Menge, 1968).

Antibodies induced by spermatozoa can interfere with fertility by at least three means: (1) inhibition of fertilization by direct action on the sperm cells; (2) embryo mortality induced by effects on the fertilizing spermatozoa; and (3) embryo mortality by action on the developing conceptus. Fertilization inhibition has been shown by treatment of semen with antiserum to spermatozoa in the rabbit (Kiddy, Stone \& Casida, 1959; Menge et al., 1962; Menge \& Protzman, 1967) and in the cow (Menge et al., 1962). Isoimmunization with spermatozoa in mice (McLaren, 1964; Edwards, 1964) and with semen and testis in rabbits (Menge, 1968) has also been shown to inhibit fertilization. Kiddy et al. (1959) reported that treatment of semen with a dilution of cattle antiserum to rabbit semen that permitted a near-normal fertilization rate increased the incidence of embryo death in rabbits. An increase in embryo loss was also reported in rabbits after isoimmunization with semen and testis (Menge, 1968) and in guinea-pigs after isoimmunization with spermatozoa (Otani, Behrman, Porter \& Nakayama, 1963). At least one semen-specific antigen has been shown to cross-react with conceptus antigens in the rabbit (Menge \& Protzman, 1967).

Whereas isoantibodies to spermatozoa can lower fertility by interfering with fertilization or embryo survival, the isoantibodies against the conceptus antigens interfered with fertility only after fertilization. Most of the induced embryo deaths appear to occur before there is a noticeable lengthening of the oestrous cycle: $75 \%$ of the return cycles were less than 24 days in length. Also the two immunized heifers that were killed 16 days after insemination had no signs of pregnancy. Isoimmunization with conceptus material also resulted in normal 
fertilization rates and lowered embryo survival rates in rabbits (Menge, 1968). Lambotte (1966) reported a reduction in average litter size in rabbits after isoimmunization with amniotic fluid. In mice, however, blastocysts transferred to females immunized by skin grafts from the strain of mice serving as embryo donors developed normally in the uterus but not in the kidney (Kirby, Billington \& James, 1966). Similarly in rabbits, no effect was noted on the survival of embryos transferred to recipients immunized against the embryo donors by skin grafting (Lannan, Herod \& Fikrig, 1964). An increased rate of embryo and foetal mortality has been reported in pregnant rats after passive immunization with rabbit antisera to rat placenta and kidney (Brent, 1964, 1967).

If local antibody production occurs in the female reproductive tract, spermatozoa at the time of insemination and fertilization might, under certain conditions, stimulate local production of antibody in sufficient quantity to cause death of the developing conceptus. Local antibody to conceptus antigens could result from resorption of a young embryo that died because of one of the naturally occurring mortality factors. There is evidence in the cow for the local production of antibody against infectious organisms in the reproductive tract (Kerr \& Robertson, 1953). Bell \& Wolf (1967) showed that the rabbit vagina is capable of producing antibodies in vitro after previous in vivo immunization. The localization of antibody to seminal antigens in the endometrium and cervical mucosa of human prostitutes has been reported by Schwimmer, Ustay \& Behrman (1967).

Whether immuno-reactions involving the antigens of spermatozoa and the conceptus occur in the female reproductive tract and whether they are responsible for a portion of the unexplained infertility in cattle is still to be elucidated. The experimental induction of these reactions, however, closely imitates the condition of repeat breeding in cattle in which there is a high incidence of fertilization failure and early embryo mortality.

\section{AGKNOWLEDGMENTS}

This investigation was supported in part by a PHS Research Grant, 9 ROI HD02376, from National Institutes of Child Health and Human Development. The assistance of R. Verville, D. Kramer and N. Vanderweide is gratefully acknowledged.

\section{REFERENCES}

BELL, E. B. \& WoLF, B. (1967) Antibody synthesis in vitro by the rabbit vagina against diphtheria toxoid. Nature, Lond. 214, 423.

BRENT, R. L. (1964) The production of congenital malformations using tissue antisera. II. The spectrum and incidence of malformations following the administration of kidney antiserum to pregnant rats. Am. 7. Anat. 115, 525.

BRENT, R. L. (1967) The production of congenital malformations using tissue antisera. III. Placental antiserum. Proc. Soc. exp. Biol. Med. 125, 134.

Camprele, D. H., Garvey, J. S., Gremer, N. E. \& Sussdorf, D. H. (1963) Methods in immunology, pp. 161, 172. Benjamin, New York.

EDwards, R. G. (1964) Immunological control of fertility in female mice. Nature, Lond. 203, 50.

KerR, W. R. \& Robertson, M. (1953) Active and passive sensitization of the uterus of the cow in vivo against $T r$. foetus antigen and evidence for the local production of antibody in that site. $\mathcal{F}$. Hyg., Camb. 51, 405. 
Kibrick, S., Balding, D. L. \& Merrin., B. (1952) Methods for the detection of antibodies against mammalian spermatozoa. Fert. Steril. 3, 419.

Kiddy, C. A., StOne, W. H. \& CAsida, L. E. (1959) Immunological studies on fertility and sterility. II. Effects of treatment of semen with antibodies on fertility in rabbits. F. Immun. 82, 125.

Kirby, D. R. S., Billington, W. D. \& James, D. A. (1966) Transplantation of eggs to the kidney and uterus of immunized mice. Transplantation, 4, 713.

LAMBOTTE, R. (1966) Mortalité foetale après isoimmunisation anti-liquide amniotique chez la lapine. C. r. Séanc. Soc. Biol. 160, 1330.

Lannan, J. T., Herod, L. \& Fikrig, S. (1964) Homograft immunity in pregnancy. Survival rates in rabbits born of ova transplanted into sensitized mothers. 7. exp. Med. 119, 781.

McLaren, A. (1964) Immunological control of fertility in female mice. Nature, Lond. 201, 582.

Menge, A. C. (1967) Induced infertility in cattle by iso-immunization with semen and testis. F. Reprod. Fert. 13, 445.

Menge, A. C. (1968) Fertilization, embryo and fetal survival rates in rabbits isoimmunized with semen, testis and conceptus. Proc. Soc. exp. Biol. Med. 127, 1271.

Menge, A. C. \& Protzman, W. P. (1967) Origin of the antigens in rabbit semen which induce antifertility antibodies. F. Reprod. Fert. 13, 31 .

Menge, A. G., Stone, W. H., Tyler, W. J. \& Casida, L. E. (1962) Immunological studies on fertility and sterility. IV. Fertility of cattle and rabbits inseminated with semen treated with antibodies produced against semen, spermatozoa, and erythrocytes. 7. Reprod. Fert. 3, 331.

Otani, Y., Behrman, S. J., Porter, C. W. \& Nakayama, M. (1963) Reduction of fertility in immunized guinea pigs. Int. J. Fert. 8, 835.

Schwmmer, W. B., Ustay, K. A. \& Behrman, S. J. (1967) Sperm-agglutinating antibodies and decreased fertility in prostitutes. Obstet. Gynec., N.Y. 30, 192. 